\title{
The Use of Chemical Weapons on the Eastern Front of World War One (1915) and its Material and Discursive Remains - the Challenge and Stimuli for Attentive Travel, Systematizing, Storage, Connecting, in situ Preservation and Making Public Real Virtual and Digital Heritage of Weapons of Mass Destruction
}

Introduction

It was truly the end of the world. Heaps of bodies lying in the streets. Just one look at those poor wretches made one weep in despair. Those in their death throes were tearing their uniforms. Young boys. What for? What is this war about?

- the author of those words, the sensitive writer Paweł Hulka-Laskowski (188I-1946) ${ }^{1}$ wondered in his description of the situation when

...one beautiful May day, hundreds of soldiers poisoned with gases were laid at the courtyards of Żyrardów schools. Those poor people were lying side by side on the ground, still wearing their worn-out, dirty greatcoats, and a few doctors and nurses from the Red Cross were walking among them, spreading their arms helplessly. There was not enough dressing and trained medical staff to save the poisoned. They were dying on ground - quietly, peacefully, without a word of protest, all dozens of them (after Hulka-Laskowski 1934: 18I).

The above account refers to May I9I5 when victims of one of the earliest, massive German chemical attacks on the Eastern Front of World War One were brought from the battlefield located about $25 \mathrm{~km}$ away, to Żyrardów, a city in Central Poland in the Masovian Voivodeship, on the Łowicz-Błońska Plain. P. Hulka-Laskowski did not try to conceal his emotions when recollecting those events. His descriptions leave no place for doubt that, even considering the aberration such as war itself, the contact with chemical weapon itself and with those poisoned by them one was a particularly intense,

I Also a translator, book-lover and pedagogue, known for his Polish translation of Jaroslav Hašek's The Good Soldier Švejk and publication of the first Żyrardów newspaper. 
disquieting and deeply depressing experience. As such, it gave rise to 'gas psychosis' rapidly spreading first in the battlefields on which the German army had experimented with chemical weapons since the beginning of I915, then to the towns, villages and settlements close to the war-zones, and with time among entire populations shrouded in poisonous gas cloud dread. As the result, using chemical weapon (CW) - both on the Western and the Eastern Fronts of World War I - started to be perceived as the psychological weapon rather than physical weapon ${ }^{2}$ and as the mysterious and unpredictable weapon rather than those that were well-known and conventional.

The so far largely excluded from the 'grand narrative' of the Great War - social and material specificities and consequences of the uses of $\mathrm{CW}$ on the wwi Eastern Front are poorly known - including aspects of the 'novelty' in the wide range of methods of killing people in the battlefield, the mass death toll, the number of poisoned soldiers, civilians and animals etc. While the issues of a military nature of chemical attacks have already been approached (see for example Kaliński 20I5; Zalewska, Czarnecki 2016), the above problems are still difficult to be considered as known. This is due to numerous factors of both epistemological and axiological nature. Written and visual records of direct experiences are rather rare, which is one of the reasons why I decided to look for 'substitute witnesses' such as the material carriers of knowledge and memory about the use of $\mathrm{CW}$ on the Eastern Front.

In this article I attempt to create a framework for perceiving, along with the discursive one, the material remains (such as landscapes, war cemeteries etc.), that are burdened with the experiences of $\mathrm{CW}$ as lasting insights that undergo continuous changes (both physically and semantically) and are constantly gaining and/or losing (depending on context) their power, agency and scientific, historical and social value. The article has four sections: the first one introduces, from the anthropological perspective, the spatial and temporal conditions of creating the specific phenomena of the gasscape rooted in 1915 and present in contemporary central Poland ${ }^{3}$. That specific gasscape as well as many other gasscapes - the list of which is unfortunately very long - are worth to be perceived as the challenges and stimuli for systematizing, storage, connecting, preservation and making public real virtual and digital heritage of weapons of mass destruction. The core of the second section is resulting from the application of historical perspective, which is helpful in getting a dense description of the primary process to the real material entities that can be perceived as triggers for reflection on the specificity of chemical weapons that have been used through history and on the selective nature of our knowledge of $\mathrm{cw}$. The third section introduces the concept of attentive travel as

2 See: Understand the development of chemical weapons during World War I and its hazardous impact at https://www.britannica.com/technology/chemical-weapon; see also Rozdżestwieński 201 .

3 The term was coined by combining the English words 'landscape' and 'gas' (attacks), and was introduced and explained elsewhere cf. Zalewska 20I3; 2016. 
helpful in stressing the value of active and causative remains (material and discursive) that are worth being documented, protected and presentified and presented in the contemporaneous contexts. The fourth section of the article refers to the specific material remains present on the historic battlefield, between Sochaczew in the north and Skierniewice in the south. It is an area located on Błonie Lowlands in central Poland, extending across the border between present-day Mazovian and Łódź Provinces. Thus, I point out several specific locations where there are material remains of the use of chemical weapons. This section focuses on the overview of the actions aimed at making available to the general public knowledge of a difficult past, including initiation of the use of weapons of mass destruction on a massive scale and in a combat situation.

That can help in activating such traces/places in real and/or virtual repository of knowledge on CW. Also, that might result in the elevation of the historic sites (selected places (in) memory) ${ }^{4}$ of World War I in the Eastern Front to the rank of 'archaeological sites', which can contribute to the establishment of 'cultural park' ${ }^{\prime}$ or even 'Historic Monument'.

4 Places (in) memory have or can have the features of classically understood places of memory (sites of memory, lieu de mémoire), but they go beyond the schematic understanding of the latter category (I explain this problem in more detail elsewhere: Zalewska 20I5a).

5 Providing arguments for the establishment of "archaeological sites" in the formula developed by the monument protection services is one of the objectives of the project titled "Archaeology of the Eastern Front of the Great War and Heritage of Military Conflicts as a Cognitive, Social and Conservation Challenge" (English abbreviation: AEF, Polish abbreviation: AFW). Other, equally important research objectives of the AFW project include: - comprehensive study of research results concerning archaeological findings and movable and non-movable historical objects interpreted as traces of military actions in central Poland in the period between I9I4 and I9I5 as part of the research conducted in I998-2018 and developing, on the basis of a specific group of findings and movable and non-movable historical objects (over 20,000 items and the area of $250 \mathrm{sq} \mathrm{km}$ ) from the period of World War I, a proposal for an interpretation key that would be potentially helpful in valorization, categorization and conservation of the remains of World War I (cf. archeomemory.pl.).

6 Establishing the 'cultural park', according to Polish law (Act on the Protection of Monuments and Guardianship of Monuments (Dziennik Ustaw 2003, No. 162, item 1568)), can provide the protection and guardianship to the relic zones that constitute the cultural landscapes. That cover immovable monuments, regardless of the state of preservation (article 6 of the Act). The 'cultural park' may be established by the Commune Council (Rada Gminy) following the opinion of the Voivodeship Inspector of Monuments. In the specific case discussed here, in my opinion, it should take place immediately, at least in relation to all surviving war cemeteries, including those where the victims of chemical weapons are buried and to the distinctive landscape grounds with the immovable monuments, where the relics of the Great War have been perfectly preserved (these are the vicinity of the villages of Joachimów Mogiły and Wola Szydłowiecka in the Bolimów commune). Then the gasscape - presented here as the case study - would become object of legal protection and guardianship provided by the Polish law, for the benefit of future generations - as a warning.

7 'Historic Monument' (in Polish: pomnik historii), the term introduced into Polish law in 1990, is one of several categories of objects of cultural heritage and the highest form 
Finally, on the background of the reflections on circumstances and effects of the initial use of the CW on the Eastern Front the entangled discursive and material remains are placed in the position of challenges and stimuli for systematizing, connecting, storing, preserving and making public, noticed as occurring in the contemporary world, material, virtual and digital traces of past uses of $\mathrm{cw}$.

\section{Spatial and temporal conditions of the use of chemical weapons in the territory of present-day central Poland in 1915}

At the end of I9I 4 and the beginning of I9I5, after bloody manoeuvre combat near Łódź, military actions in the Eastern Front reached a more static phase, defined as stationary warfare. Since autumn 1914, the soldiers of the Russian Empire had been preparing a reserve defence line, stretching from the outlet of the Bzura into the Vistula as far as the Pilica. The total length of the Eastern Front was at the time around $1200 \mathrm{~km}$, from which $800 \mathrm{~km}$ crossed the area of present-day Poland where, at the section of around $\mathrm{I} 7 \mathrm{~km}$, the events discussed below took place (Fig. I).

On the Russian side, that section of the front line was held, in the most part, by the $2^{\text {nd }}$ Army under command of General Vladimir V. Smirnov and partially by the $\mathrm{I}^{\text {st }}$ Army under command of General Alexander I. Litvinov. The units fighting on the German side belonged to the $9^{\text {th }}$ Army, initially under command of General August von Mackensen, and then, since April I915, under command of Prince Leopold of Bavaria. Over 3 million Poles, conscripted into the armies of the invaders, took part in fratricidal fighting in the territory of present-day Poland (cf. Archeologiczne przywracanie... 2019: 9-10, further reference provided therein).

The commanding officers of the Army of the German Empire, having learnt the lesson of experience in the Western Front, did not want to allow the Russian defence lines to fully stabilize. Thus, they persistently tried to break the stabilizing front line at several crucial sections. One of such key sections of the front line was located around $60 \mathrm{~km}$ to the west from Warsaw. The Russians took defensive positions on high eastern banks of the rivers Bzura and Rawka, as relatively easy to hold. However, at the several-kilometre-long section stretching from the outlet of the Rawka into the Bzura, the low and marshy eastern bank was not suitable for defence and the Russians had to move the front line back by around $3 \mathrm{~km}$ from the Rawka. Thus, it ran through the villages of Zakrzew, Sucha, Borzymów, Humin, Wola Szydłowiecka and Mogiły, which were fortified. That section of the front line was considered crucial by the Supreme Army Command

of protection under Polish law. There are many arguments in favor of establishing this rank of protection and significance in relation to the gasscape described here. 


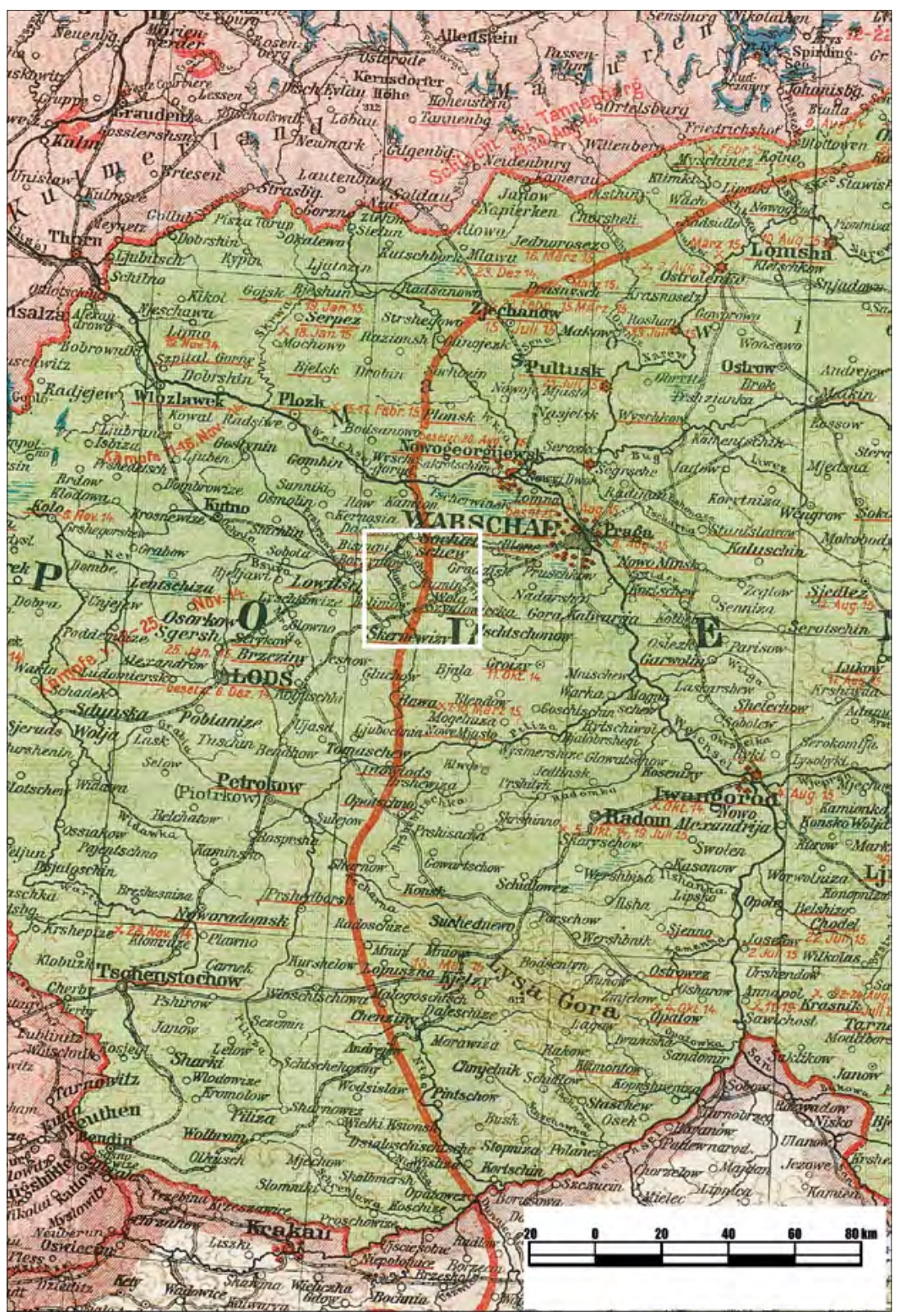

Fig. 1. Schematic course of the Eastern Front line in 1915, in the section from Skierniewice (south) to Sochaczew (north). In the area marked with the white line the Germans carried out gas attacks in the period between January and May I9I5 (Author's elaboration of data on the German map from 1915, from the private collection of J. Czarnecki). 
(Oberste Heeresleitung, OHL) due to the relative vicinity of Warsaw ${ }^{8}$. It was also thought to be the most convenient spot to make a breach. Therefore, for the entire January 1915, the Germans tried to penetrate the enemy lines there, but without success (for more details on the historical background of the events cf. Zalewska 2013: 69-73; 2016; Archeologiczne przywracanie... 2019; Kaliński 2015; Zalewska, Czarnecki 2016; 2019).

As early as in January 1915, the German army decided to use chemical weapons at the discussed section of the Eastern Front in the region of the rivers Bzura and Rawka. The Germans stocked up with at least 18,000 shells containing irritants (hereinafter referred to as "tear gas") (see details at Zalewska, Czarnecki (in print)). Similar firing tests with the use of then-pioneering weapon of mass destruction took place in the areas south to Sochaczew (several kilometres away from the town), near the villages of Zakrzew and Boryszew, and $\mathrm{I} \mathrm{km}$ to north of the village of Humin. Gas shells were used by the Germans several times, especially during the fire attack on the forest-covered area of the so-called Hill No. 95) (see details concerning the landscape conditions of the Humin key point and "Wzgórze 95" in: Zalewska et al. 2019: 82-92). It was one of key defence positions of the Russian army in the region of Bolimów. The south end of Bolimów lodgement, in the region of Mogily cottage, was probably another target of the so-called 'stinky shells' (see details concerning the Joachimów Mogiły key point in: Zalewska et al. 2019: 65-78).

In the period between January 31 and February 5, 1915, during the 6-day battle at this section of the front line, in addition to gas shells fired at the positions of the Russian army - from the Borzymów Forest (in the vicinity of present-day village of Reduta) to Borzymów (present-day village of Borzymówka), Humin and Wola Szydlowiecka, and further to the west, in the direction of Mogity - German artillery shot also many thousands of conventional shells of various calibres (from $7.7 \mathrm{~cm}$ to the heaviest $30.5 \mathrm{~cm}$ ). During that battle the Russians lost around 40,000 soldiers (wounded, killed and missing), while German losses were several times lower.

As a result, the Russians deployed in the vicinity of Humin and Wola Szydłowiecka, as well as those holding positions to the west of those villages, retreated to the east by several hundred meters to over one kilometre. However, neither the heavy, many day's long cannonade, nor the use of gas shells, nor even attacks by the German infantry repeated every few hours, managed to breach the Russian defence. Finally, in January, the Army of the Russian Empire, having defended their positions, initiated stationary warfare that in that particular region lasted

8 Warsaw, the capital of Poland since the $16^{\text {th }}$ century, and then-capital of province in the part of the country occupied by tsarist Russia, was in that time also an important economic and communication centre. 
until July 1915. The combat that evolved into static trench warfare stayed that way untill July igis and became similar to the stalemate of the Western Front (Zalewska, Czarnecki 2019). Also, similarly to the Western Front, the warring parties, over time used not only conventional weapons, but also chemical weapon. After January attacks with tear gas shells, wave attacks with the use of poisonous substances, in particular chlorine (and phosgene?), took place (for more details cf. Zalewska 2013; 2016; Archeologiczne przywracanie... 2019; Kaliński 2015). Currently, the fact of using chemical weapons by the Germans at the beginning of January I9Is is often marginalized and/or questioned.

\section{Chlorine and phosgene (?) on the selected episode on the Eastern Front in 1915}

In spring of I9I5, the Army of the German Empire were still trying to breach the Russian defences and put an end to the exhausting and bloody stationary warfare. One of the methods that was also supposed to minimize their own losses was the use of poisonous gases. The originator of the idea of using chlorine as a military agent was prof. Fritz Haber, later Nobel laureate in chemistry (Friedrich, James 2017). WMD used by the Germans was at the time the most technologically advanced non-conventional weapon, perceived as a potential solution to make a breakthrough. Its use in combat situations required breaching conventions that limited the possibilities of using chemical weapons. However, this was often a disputable issue (cf. Spiers 2016; Innocence Slaughtered... 2015).

Wave attacks, also called 'gas cloud attacks', based on releasing the gas simultaneously from many cylinders containing liquid chlorine, required special preparations. The cylinders were placed in such a way so as to make sure that the released gas would create a uniform cloud of an appropriate, lethal concentration, moving with the wind in the direction of enemy trenches. That method was selected due to the impossibility of applying any other effective technique of killing the enemy with gas. It was the most unpredictable weapon in the arsenal of the German army. However, despite its shortcomings, only several months after the first German attacks, in spring of 1915 , the solution was also adopted by British, French and Russian armies (Lepick 1998; Spiers 2016).

In order to carry out a successful gas wave attack, at least four elements were required: tools, people, favourable landscape conditions and optimal weather (Bartel 1928; Martinetz 1996). Preparation and/or adaptation of an enormous number of gas cylinders that could be used for a wave attack, along with special equipment, required trained staff who knew how to handle that new weapon. In mid-January of 1915 , the first unit assigned to operate gas cylinders was formed. Initially, the unit consisted of 500 soldiers under command of colonel Peterson, 
a sapper officer from Königsberg. To hide its true purpose, it was called 'Pionierkommando' or 'Desinfektiontruppe' (Stoltzenberg 1994). Military conditions and the specific character of gas attacks in the discussed area have already been described (cf. Kaliński 2015; Zalewska 2019; in addition, the issue of tools and nature-cultural conditions of the so-called dirty weapons will be discussed in the next volume of this journal).

Only several days after the gas attack near Ypres in Belgium, which took place on April 22, 1915, the soldiers of the $36^{\text {th }}$ Pioneer Regiment, formed for military actions in the Eastern Front, were deployed in the vicinity of Gorlice. OHL planned to launch a massive strike there to break through the Russian lines. However, officers of the $36^{\text {th }}$ Regiment decided that landscape conditions of the Low Beskids made it impossible to carry out a gas attack with the use of chlorine. They were afraid that the hilly and mountainous terrain, covered with dense forest, could be an obstacle for a successful wave attack, i.e. according to then-applicable gas using tactics.

The next place selected by the German command for the use of WMD was the battleground by the Bzura and Rawka, more precisely the so-called Bolimów lodgement on the eastern banks of those rivers. That section of the front line stretched from the village of Zakrzew (by the Bzura) in the north to the vicinity of Mogity cottage (by the Rawka) in the south. The land offered optimal conditions for an effective wave attack - it was relatively flat and the line of the planned attack would cross forested areas in only three spots. The issue of terrain/landscape conditions that provides a spatial context for wave attacks in I9I5 has been already discussed in detail elsewhere (cf. Zalewska et al. 2019).

The documents of the $9^{\text {th }}$ Army of the German Empire reveal that the Germans depended on the lethal effect of poisonous combat agents and prepared for an attack with two corps in the direction of Blonie (around $30 \mathrm{~km}$ away from Warsaw). In terms of landscape conditions, the area selected for the use of poisonous gases was not much different from that which had been previously cannonaded with tear gas shells. Haber once again chose chlorine as an active substance, since it was inexpensive and produced on a mass scale as part of many manufacturing processes. The first gas attack with the use of chlorine in the Eastern Front took place at a section of the front line around $14 \mathrm{~km}$ long that stretched between Zakrzew and Sochaczew in the north in the direction of Humin in the south and Wola Szydłowiecka in the south-west, reaching as far Majdan Bolimowski (present-day surroundings of the village of Joachimów Mogity). Soldiers of the $9^{\text {th }}$ Army of the German Empire deployed I2,000 steel cylinders filled with chlorine. They assumed the usage of around 240 tonnes of gas, i.e. 100 more tonnes that had been used at Ypres!

After many days of waiting for favourable wind conditions, the wave attack was finally carried out on the $3 \mathrm{I}^{\text {st }}$ of May 1915. The gas used during that attack 
was lethal chlorine. However, according to some sources, instead of using pure chlorine, a mixture of chlorine and $5 \%$ of phosgene was used by the Germans at the Rawka (Haber 2002: 37; Lepick 1998) ${ }^{9}$. It was supposed to increase the lethal effect. After opening the valves, when the gas cloud passed over the Russian positions and Russian soldiers still resisted the attacks, the German command was convinced that gas, carried with too strong gusts of wind, did not cause significant damages in the ranks of the Russian army. Apart from the wind, the apparent "failure" was ascribed to "eggheads", especially to professor Fritz Haber, who was personally present at front line (cf. Prinz Leopold von Bayern I915: 176). Lack of artillery involvement was also considered a serious mistake.

Nevertheless, for the Russians those wave attacks with the use of gas cylinders were something totally unexpected and never seen before, as proven by Liddell (1916: 2) and his multiple mentions of gas shells, not gas cylinders, in his straightfrom-the-front accounts published in a book and numerous articles written for British newspapers.

Let me look back and tell you of some incidents.

On the night of May 30 and early morning of May 3I, 1915, and again on July 6 and 7, the Austro-German forces attacked with gas shells. The Russians lost twelve thousand men. Later on you will read of these attacks. I saw the dead and dying men lying amongst the men who coughed and gasped for life. One bearded giant lay at the edge of a Red Cross camp. I bathed his head with water and gave him milk to drink and rearranged his pillow. "Neechevo!" he said to me, and smiled bravely with his fine blue eyes, full as they were of dreadful pain.

After the retreat of the Russian Imperial Army in July 1915, the German command realized how great a mistake was committed in their assessment of the effects of the May wave attack. The commanding officer of the $9^{\text {th }}$ Army noted that inscriptions found at Russian cemeteries situated behind the front lines. proved there were a great number of victims of that particular attack. Thus, by 1915 cemeteries had already bore testimony to and provided material evidence of the tragedy that, in statu nascendi, proved to be problematic to interpret even for eyewitnesses of military actions with the use of weapons of mass destruction. Unless such an eyewitness was on the other side of the front line, like Liddell, who wrote:

We dug graves for the men next days. One very large one and another. In the former were buried one hundred and eight men, and in the latter, thirty-five. Such graves are called

9 Olivier Lepick mentions two versions of that mixture. According to French authorities investigating the events after the war, the gas used for the attack contained $20 \%$ of phosgene. On the other hand, L.F. Haber, referring to German sources, describes a mixture with $5 \%$ phosgene content. 
"fraternal". The men were buried in their clothes - just as they had died. But first we took their belongings from their pockets, in order, if possible, to send them to their relatives. They were pathetically interesting. Almost every man had a purse, but very little money. The whole number had not a hun (Liddell 1916: 55).

The reporter, despite being a very keen observer, as proven by his book and articles, was not particularly precise as regards the locations of the described events and proper names. His notes - especially those concerning the events of May and June 1915, which are very useful in interpretation of material remains of using chemical weapons in the Eastern Front, can be found in the chapter titled "Staro-Radziwiłłów" (Liddell 1916). In that account, he describes the reality of the area right behind the front line, focusing on the functioning of field hospitals and Red Cross camps, as well as the activity of the $7^{\text {th }}$ voluntary group of the Red Cross and the quarters of sisters of the Red Cross, located around $0.5 \mathrm{~km}$ away from the hospital. According to Liddell, one of those hospitals was situated at the edge of a forest near Radziwiłłów station. Tracks of a narrow-gauge railway, used to transport people, ammunition and the wounded, ran across the fields in that area. That makeshift railway (using 2 horses as the pulling power) "each hour" brought the wounded from the battlefield. Its tracks were laid on bare ground and reached the back trenches of the Russian army. They were located around $5 \mathrm{~km}$ from the hospital (according to: Liddell 1916: 48, 52, 58 ).

Another important subject in the accounts of the war reporter were funeral circumstances and cemeteries where soldiers, including the victims of gas attacks, were buried. The deceased were buried in their uniforms and boots (although accounts from other sections of that part of the front-line mention burials in underwear only). Graves - both mass and individual - were dug in sandy soil (Liddell 1916: 53, 58). Those were the resting places of victims of the use of chlorine with possible addition of phosgene by the German army. Although material traces of those camps and field hospitals have not been precisely located yet as part of a field survey carried out for that purpose ${ }^{10}$, two cemeteries have already been discovered and documented in the area behind the Russian front line. Those are most probably hospital cemeteries described by Liddell. Their remains, increasingly more difficult to discern in the field, can be found in situ. The war cemetery in the village of Jesionka in the commune of Wiskitki have been, unfortunately, transformed to a great extent as a result of forest management (Fig. 2).

Io Surface examination in the area covered by the 6I-60 sheet of the Archaeological Photograph of Poland (Archeologiczne Zdjęcie Polski - AZP), carried out as part of the project "Archaeological Restoration of The Memory of the Great War. Material Remainders of Life and Death in the Trenches of the Great War in the Region of the Rivers Rawka and Bzura" was one of stages in the research project No. 2013/10/3/00406 financed from the resources of the National Science Centre in the period 20I4-20I8. 

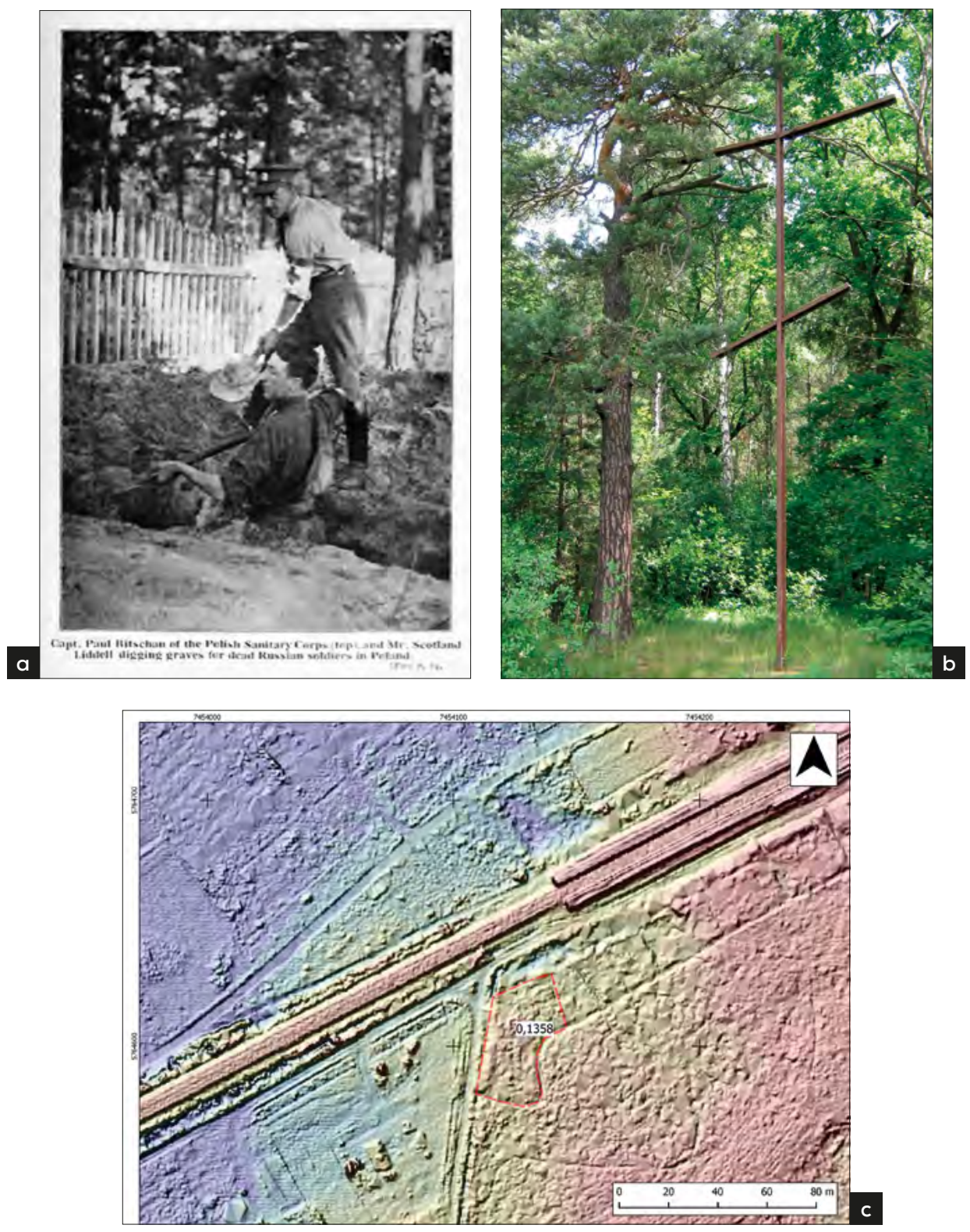

Fig. 2. War cemetery in the village of Jesionka: a. Archive photograph of R.S. Liddell digging a grave, printed in the publication On the Russian Front (I916); b. Present-day view of the ploughed and forgotten war cemetery with a cross; c. Digital Terrain Model showing the scale of topographic destruction in the area of the cemetery (DTM by G. Kiarszys). Developed by A.I. Zalewska. 
However, due to the palimpsest character of that cemetery, i.e. overlapping layers from the first and the second world wars, as well as a very unique cross, the place still remains evocative. The original shape of the second of the above-mentioned cemeteries, probably located in Franciszków, is also not evident.

The second gas attack with chlorine occurred on the $\mathbf{I}^{\text {th }}$ of June 1915. Due to logistical problems, the section of the front line selected by staff officers of the $9^{\text {th }}$ Army as the location for the attack was considerably shorter than the previous one. On the $9^{\text {th }}$ of June, the commander of the $36^{\text {th }}$ Pioneer Regiment reported to the command of the $9^{\text {th }}$ Army that he had 18,000 cylinders at his disposal and was ready to carry out another gas attack. In addition, the attack was to be accompanied by "concentrated actions of the artillery". Artillery preparations began on the $\mathrm{II}^{\text {th }}$ of June, around 9 a.m., and the gas release was planned for the afternoon. However, an approaching storm forced the command to change their plans. Thus, the cylinders were not opened until 3.30 the following morning, after an intense artillery preparation of the $4 \mathrm{~km}$ long front-line section in the vicinity of Sucha and Zakrzew villages. As the weather conditions changed yet again, prof. Haber tried to cancel the attack, but he did not fully succeed. Gas release from the cylinders was partially stopped at the southern section, but the northern wing did not receive the order in time.

As a result, the gas cloud passed first through German positions, and only after some time was it carried by the wind in the direction of Russian lines. The event was described in such sources as the chronicle of the $128^{\text {th }}$ Infantry Regiment:

In the front trench, Stieberitz played loudly the March of the $128^{\text {th }}$ Regiment. The soldiers began the storm. However, they barely managed to make a few steps when the gas cloud drifted back to our ranks. The wind changed. People were unable to catch a breath. Carrying on with the attack, we risked yet another failure. This caused confusion among the sub-units. They pulled back. We suffered losses in connection with the gas. The music stopped abruptly. Only one soldier remained at his post with a machine gun, in the middle of the gas cloud [...] (Richter I931: I23 et seq.).

Russian soldiers fighting in the front line fell lifeless to the ground or suffered such heavy poisoning that were unable to fight on. Many of them, realizing that a wave gas attack had started, fled from the field. The chronicler of the $128^{\text {th }}$ Infantry Regiment also wrote that:

On the other side of the front line, people saw Russians trying to save themselves by climbing up trees and the railway embankment (Richter 1931: 123).

The soldiers of the $175^{\text {th }}$ and the $128^{\text {th }}$ Infantry Regiments breached the Russian lines and proceeded towards further enemy positions. At the same time, soldiers of the $8^{\text {th }}$ Reserve Infantry Regiment crossed the Bzura and attacked the Russian 
forces from the flank. The June gas attack was so effective that, for the first time in 6 months, German soldiers managed to penetrate deep into Russian positions - as far as $3 \mathrm{~km}$ ! - at a $6 \mathrm{~km}$ long section of the front line, even though the Germans used 'only' 4500 small gas cylinders. One day after the attack, the newly-acquired positions near the village of Zakrzew were visited by the supreme commander of the $9^{\text {th }}$ Army, Prince Leopold of Bavaria ${ }^{11}$, who described the event in the following words:

Nearby, there was located the most-protruding Russian trench. A few dead bodies of enemy soldiers were still lying there. One could notice the effects of poisonous gases that passed through the area. Most of dead Russians had black faces and hands. Their mouths and noses were covered with cotton bands, faces pressed to the ground, metal elements of their weapons bleached, high crops withered, tree leaves and grass burnt brown and gold; I have even spotted a dead dog cuddled up to his dead master (Prinz Leopold von Bayern 1915).

Part of German soldiers killed in the June attack were probably buried in the Kozłów Forest near Zakrzew, to the north of the village of Nowa Sucha (see: details concerning landscape conditions of the key point near Zakrzew village and the outlet of the River Sucha to the Bzura, marked out as a result of archaeological and remote sensing research, vide Zalewska et al. 2019: I13-126). That cemetery was ploughed in the course of execution of the forest management plan in the surrounding area. Hence, its surface shape is barely noticeable (Fig. 3). Within present-day administrative boundaries of the commune of Nowa Sucha, there are still present war cemeteries with graves of possible victims of chemical attacks. Currently, the most noticeable is the one in Borzymówka. Detailed information on war cemeteries in the commune of Nowa Sucha has been provided elsewhere (see: Zalewska et al. 2018).

The third and last gas attack with the use of chlorine in the region of the rivers Bzura and Rawka took place on the $\mathbf{6}^{\text {th }}$ of July $\mathbf{1 9 1 5}$. It was originally planned for the $17^{\text {th }}$ of June, but during artillery preparations the wind direction kept changing. So, it was not until almost three weeks later that the valves of chlorine cylinders were opened. The gas was supposed to be released along the section of the front line between Borzymów and Humin. Prince Leopold of Bavaria, as the commanding officer of the $9^{\text {th }}$ Army, did not conceal his frustration at the fact that gas was being released without an attack plan and without any chance to breach the Russian defence. Finally, the gas was released at the section of the front line between Wola Szydłowiecka and Borzymów, although the cylinders were also

II It should be also emphasized that, two days after the attack, the conquered Russian positions in the vicinity of Zakrzew were visited by Emperor William II, who was bursting with pride in the successes of his army. 

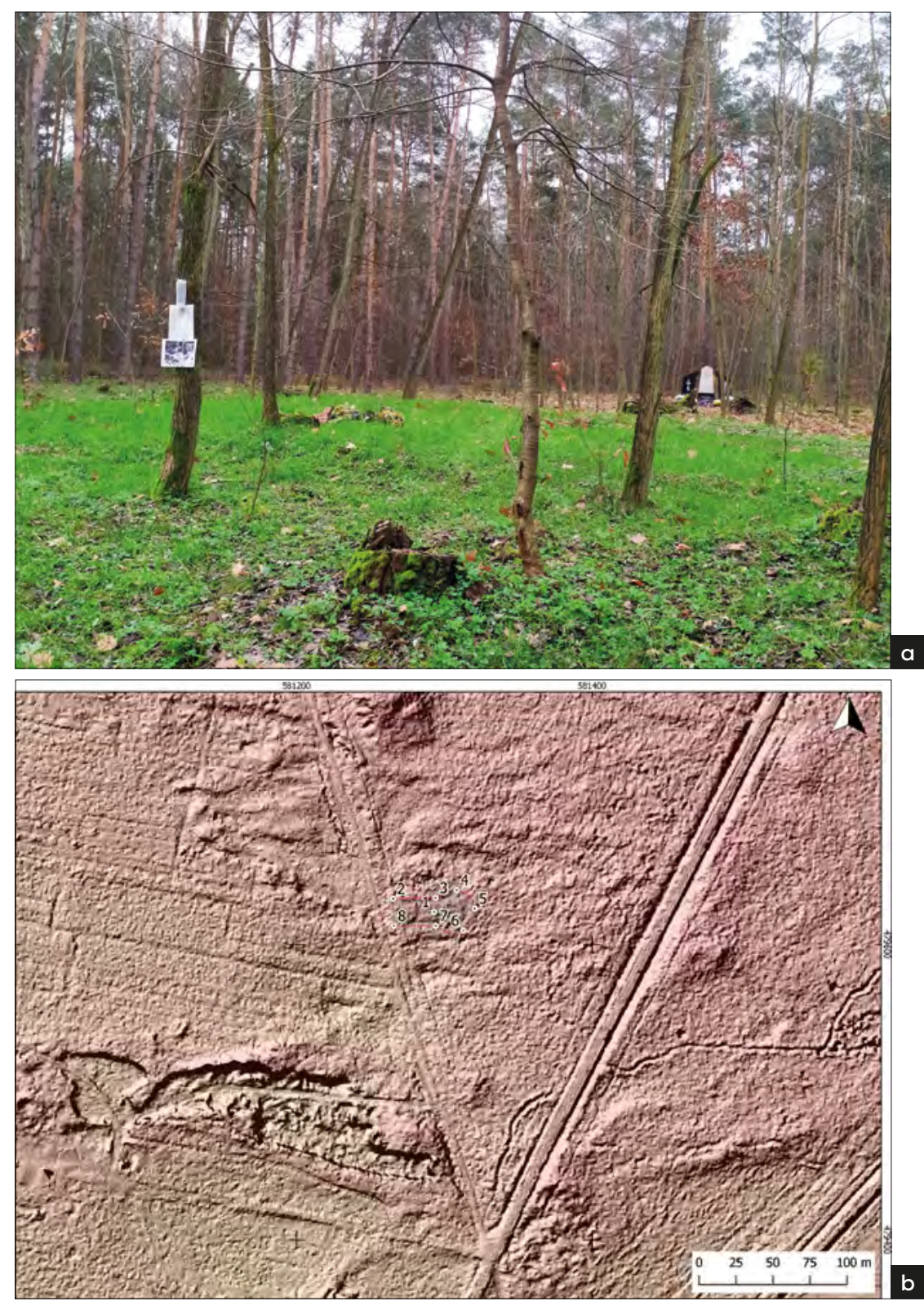

Fig. 3. War cemetery, close to the villages Kozłów Biskupi amd Zakrzew in the area of Nowa Sucha Commune: a. Present-day view (2020) of that war cemetery - a memorial site for victims of chemical weapons from June 1915, that started to be restored as a result of archaeological research; b. Digital Terrain Model (DTM by G. Kiarszys). Developed by A.I.Zalewska. 
deployed to the north of Borzymów. Once again, due to a change in the wind, chlorine (or its mixture with phosgene) was not released from all cylinders. The wind pushed the poisonous cloud in the direction of German positions, causing serious casualties:

At 9.45 p.m., the entire front was illuminated with red balls of light. Valves were opened and gas started to flow in the direction of the Russians. But what is that? It seems that the gas cloud is going back to our positions. [...] Eyes start to water, we have terrible fits of coughing. What shall we do!? (Gebhardt 1933: 33-34).

The regiment chronicle also mentions that the attacking soldiers entered a cloud of chlorine fumes when its further movement was hindered by unharvested crops in the approaches to the enemy lines. That factor had not been previously taken into account as an obstacle for a gas attack. As a consequence of blocking the chlorine by crops and releasing the gas against changing wind, many soldiers of the German army were poisoned. Their graves act as reminders of those events. There is some evidence that German casualties of chemical weapons by the German army were buried in such places as the war cemetery in Humin, and next to the Church of St Anne in Bolimów, that served as quarter for the so-called Gassregiment (although currently there are no visible surface traces of burials close to the church).

During the July attack, the Russian army suffered heavy losses in men. In one of the reports of the $218^{\text {th }}$ Regiment, the adjutant of the regiment wrote:

A huge amount of gas spread along the entire front line held by the Regiment, killing everything on its way [...] The Regiment was unable to hold its positions due to heavy losses in men. Casualties: IO officers and I5 I privates killed, 1992 soldiers missing in action... (as cited in: РгвиА, $\Phi: 2019$ O:I A:84).

Despite losses suffered by the Russian army, exposed to gas and artillery attacks, German forces did not make an advance. They followed the order of the commander of the $9^{\text {th }}$ Army not to take over Russian trenches, but only penetrate them. In the village of Humin and the surrounding area, there still can be found numerous graves, including those in the war cemetery with an unfinished monument (Fig. 4).

The total number of soldiers of both armies who lost their lives as a result of the use of chlorine (and possibly phosgene) in the Eastern Front in the first half of I9Is and the complete list of places where victims of chemical weapons are buried in the lands of today's central Poland is still unknown. Any attempt at making such calculation with respect to the victims of chemical attacks by the Bzura and Rawka - apart from realizing how problematic it is to conduct such research 


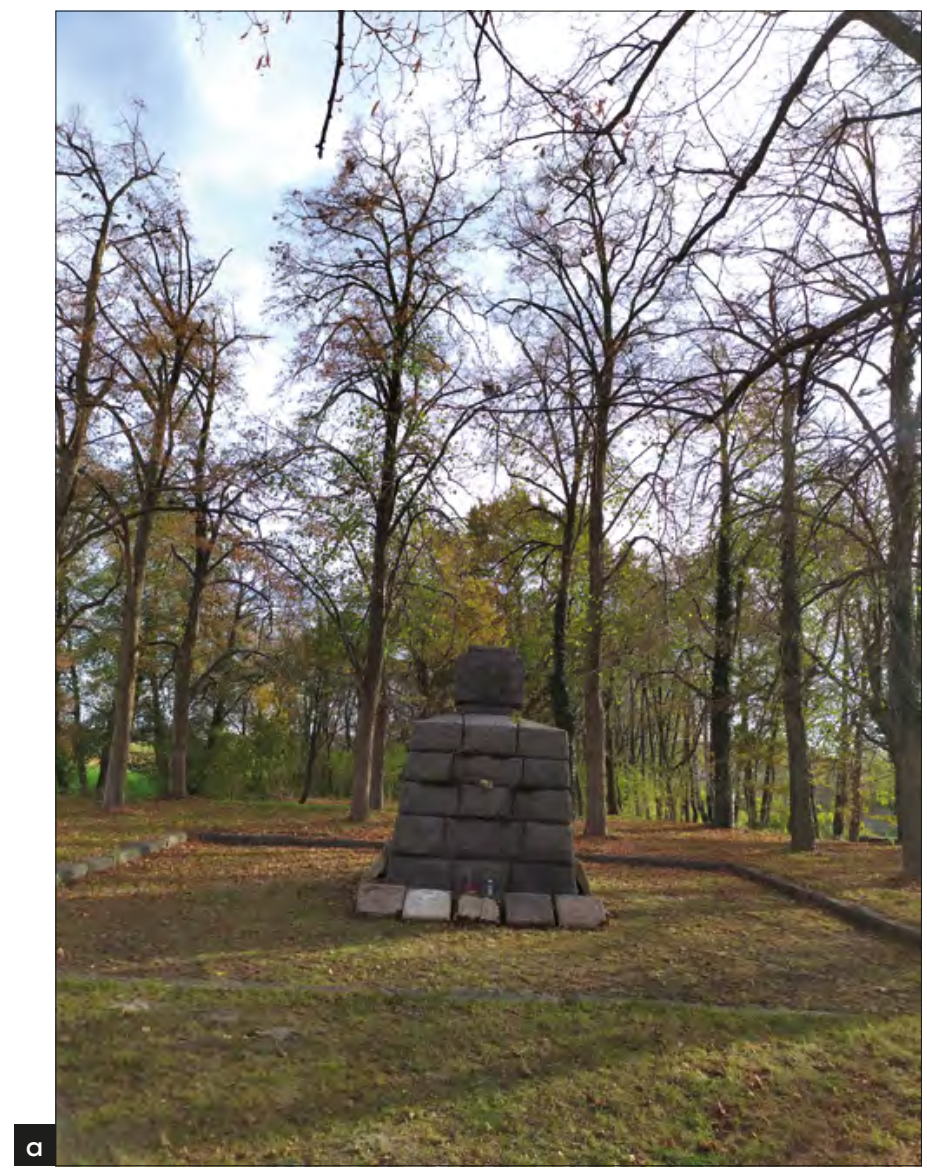

Fig. 4.

War cemetery

in Humin in the

area of Bolimów

Commune:

a. Present-day view of that war cemetery restored as a result of grassroots activities with the support of entities responsible for caring for war cemeteries in Poland; b. 3D Digital Terrain Model. (DTM by Grzegorz Kiarszys). Developed by A.I. Zalewska.

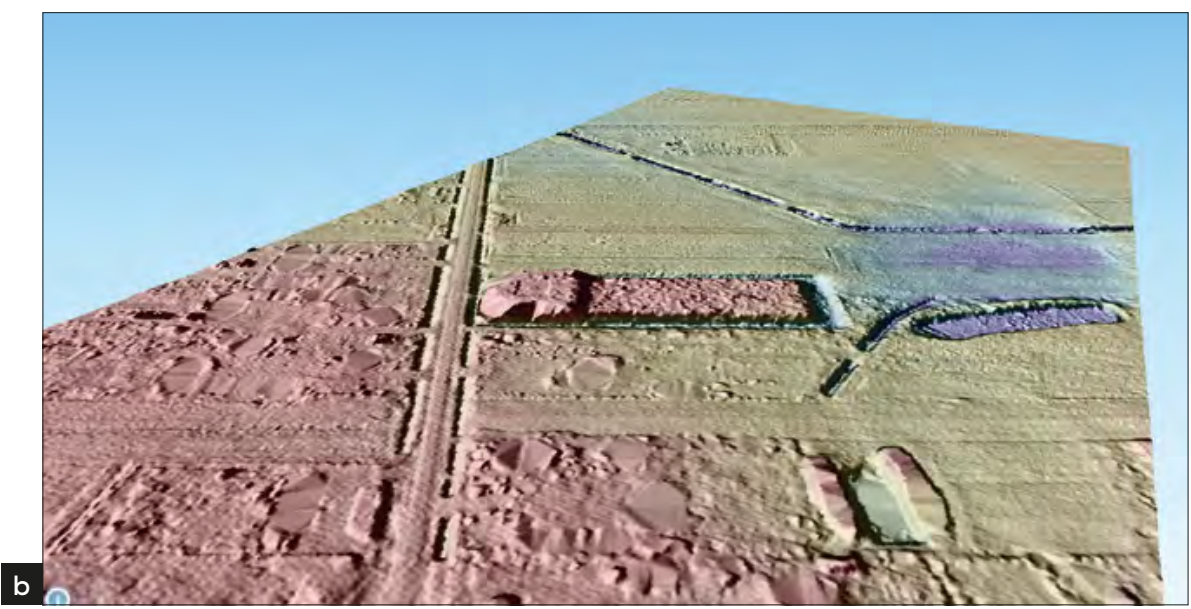


when all one can find are concealed facts, denials and manipulations, and those few available accounts are very often written in the spirit of then-prevailing ideology - can only result in an estimation.

Nevertheless, in-depth research conducted as part of the Archaeology of the Eastern Front of the Great War project allows researchers to come to the conclusion that there is some evidence to support the following estimation: in the Eastern Front, in the region of the rivers Rawka and Bzura, in the section of the front line between Sochaczew and Skierniewice, at least 22,000-25,000 soldiers of both armies fell victims to German chemical wave attacks with the use of poisonous chlorine, with possible admixture of phosgene. That number includes at least 4000 soldiers of the Russian army who were lethally poisoned at the battlefield ${ }^{12}$. However, that estimation is hardly precise, as it is based on numerical data in archive documents and secondary data reconstructions.

Soldiers poisoned with gas were buried in both individual and mass graves in the area taken over in the course of military actions of the Army of the Russian Empire, including such locations as Guzów, Kozłów Biskupi, Jesionka, Kurdwanów, Miedniewice Wola Szydłowiecka, or even Szymanów, but also further from the battlefield, e.g. in Warsaw or Żyrardów. Other graves can be also found in the area seized by the Army of the German Empire in 1915, including Bolimów, Borzymówka, Humin and Wola Szydłowiecka.

\section{'Face to face' with the materiality of gasscape and/or virtual walk into a digital repository of knowledge on $\mathrm{CW}$}

At many levels, remains of using chemical weapons (as for example remains from the World War One Eastern Front), constitute a serious cognitive, conservator and social challenge. As the significant reasons for the cognitive complications can be pointed the volatile nature of the traces of the uses of chemical weapon and deliberate concealment of activities and outputs related to $\mathrm{Cw}$, especially in the initiation phase (as in the actions of 1915). Despite that, remains of volatile 'dirty weapons' are still accessible today, such as places that can be treated as the carriers of memory, since they allow the still rudimentary social and historiographic knowledge of the initial phase of introduction of chemical weapons in combat

I2 This is only estimated calculation by the author of this article, made on the basis of available data from Russian and German sources, the most helpful of which proved to be materials collected by Rossijskij Gosudarstvennyj Voenno-Istoričeskij Arhiv (RGVIA - РГвИА) and German archives: Hauptstaatsarchiv Stuttgart (HStAS), Bundesarchiv-Militararchiv Freiburg and Br. (BArch) and BayHStA - Bayerisches Hauptstattsarchiv in Munich. I also would like to thank Jacek Czarnecki for his cooperation in searching for and translating data concerning the victims of gas attacks found in source materials. 
situations in the Eastern Front of World War I to be materialized. They are also supra-local symbols of difficult heritage that, despite their significant transnational value, have not been previously subjected to a systematic analysis.

Attentive travel is one of the potential forms of interaction with such remains. It can form difficult heritage of weapons of mass destruction, including material remains of using chemical weapons. It seems especially appropriate in relation to the issues discussed herein, as it both falls within and deepens and expands the scope of understanding of that type of activity as cultural tourism whose general subjective definition is as follows:

the journey of people to specific destinations that offer cultural attractions, including historic sites [...] with the aim of acquiring new knowledge and experiences that meet the intellectual needs and individual growth of the traveller (McKercher, duCros 2003).

Cultural tourism in itself is a multi-aspect phenomenon, only seemingly easy to define and plan (see for example the very valuable reflections on the complexity of that social phenomena from a geographic perspective, contained in the publication Kowalczyk 2008, there also further literature). As recorded therein, since the very beginning of tourism as a social phenomenon, cultural tourism has comprised cognitive (educational) tourism (according to the typology proposed by K. Przectawski 1979), however some of its forms expand the framework of the definition. Detailed definitions of cultural tourism can be divided into four categories: definitions focusing on destination's resources; definitions focusing on tourists' motivations; definitions focusing on empirical or aspirational aspects; and definitions that have fundamental importance for specific research objectives (see: McKercher, DuCros 2003). As regards those four dominating types of definitions, particular attention is given herein to issues arising from the one that focuses on the characterization of tourist destination. This can be done among other ways by defining and widely presenting 'destination's resources' such as for example the specific group of material remains - places that bear testimony to the use of chemical weapons (such as gasscape on the Eastern Front from 1915), whose detailed descriptions were provided as a result of making them the focus of archaeological, historical, landscape and memory studies. Those remains are characterized by their great historic and scientific value.

Assuming that the practice that I propose to call real and virtual attentive travelling slightly exceeds the existing framework of cultural tourism, as well as other useful and expected activities for the purposes of outreach and education, including establishing a connection with and understanding of painful heritage of $\mathrm{CW}$, the problem requires further elaboration. It is worth doing, as deepening the methodological and methodical reflection might contribute to social appreciation and protection of experienced places such as gasscapes, as areas of potential 
positive impact on the future of humanity. With that in mind I suggest to take on the general level the following measures:

- more serious and attentive treatment of spatial and materials aspects of places of historic events of high scientific and social value;

- more intensified outreach and educational actions aimed at popularization of knowledge of cultural heritage (including painful transnational heritage) and

- effective connection (cross-linking) of the actual reality (elements that are still physically present in the landscape) with subjects of discourse and recognition (included in archive documents, studies, etc. that can together make up a possibly entangled virtual (incl. digital) and real (incl. material) repository/repositories of knowledge on $\mathrm{CW}$ and $\mathrm{WMD}$ and potentially many other related experiences from recent past that shaped us and shape our future.

\section{Material remains of using chemical weapons by the German Empire in the Eastern Front (1915) as a stimuli for systematizing, storage, connecting, preservation and making public real, digital and virtual cw heritage}

The material remains of using chemical weapons, including gas shells and wave attacks, by the German army in January, April, May and July of 1915 , which are the subject of this study, so far were discussed idiographically ${ }^{13}$. However, I suggest to consider attributing also the nomographic character to some conclusions arising from the implemented research into the above-mentioned issue, i.e. that stimulation of historical consciousness and sensitivity could and should encourage the development of in-depth historical awareness and the feeling of safety, not fear. At the same time I am trying to convince archaeologists, historians and the local stakeholders of the painful heritage that can be actively engaged in though the process of outreach and education on $\mathrm{CW}$ and $\mathrm{BMR}$, by spreading knowledge about the history, the potential threats and the mission and activities of entities involved in the process of minimizing the threats of weapons of mass destruction in the modern world, such as the Organisation for the Prohibition of Chemical Weapons (OPCW).

I3 The reflections presented below are based mainly on the case study from the region of the rivers Bzura and Rawka which was the subject of research "Archaeological Restoration of the Memory of the Great War. Material traces of the life and death in the trenches of the eastern front and the transformations of the battlefield landscape in the region of Rawka and Bzura" carried out in 20I4-20I8 (English abbreviation: ARM; Polish abbreviation: APP). The research was dedicated to studying the daily lives and deaths, as well as the material and social memories of those engaged in the fight during WwI. The ARM project was financed with the grant from the National Science Centre awarded under decision number DEC-2OI3/IO/E/HS3/00406 (see Archeologiczne przywracanie... 2019). 
Currently, the history of gas attacks in the Eastern Front finds very little support in material traces (cf. Śliwakowski, Chałas 2019). As regards written sources, such as reports, journals, archive documents and later studies (dating back to the twenties and thirties of the previous century), information concerning the use of weapons of mass destruction in 1915 often has to be extracted from tacit verbis. However, as I try to show in this article, after Ios years it is still worthwhile to reflect for a moment on the peculiar nature of weapons of mass destruction from the perspective of purely human, spatial and material aspects of their use in the territory of present-day Poland in 1915. In addition, an opportunity to directly confront the material (geospatial) aspect of gas attacks, including the landscape that bore witness to those events, along with burial sites of victims of chemical weapons, is particularly precious. This provides an important basis for making the local history take on a global dimension. It is possible in both physical and virtual space. However, it would require a repository to store the collected, systematized data on individual locations of gas attacks, including their geospatial characteristics and source data, along with iconographic and text contents, and in several cases also video or even audio materials - registered interviews with witnesses of gas attacks (in the 1980s) and descendants of residents of the area of the battlefield (in the period I915-1920).

An insight into the specific character of the area of gas attacks, including its landscape could be provided with the use of many generally accessible tools that would allow travel across the gasscape in both physical and virtual reality. Our previous efforts could be characterized as 'analogue-based'. However, the wealth of knowledge contained in already published works and other durable media, shared by means of museum exhibitions and information boards, could be elevated from the local material (real) level to the transnational virtual (digital) dimension with the use of appropriate tools and technologies.

The basis for creating such repository of knowledge could be geospatial data combined in digital space (cross-linked with metadata resources dedicated to individual places and events), as well physical places as such, especially graves and war cemeteries (see: Zalewska, Cyngot 2017; 2020). Localization of the latter could be facilitated for example by the in situ boards marking an educational and historical path created on the initiative of "Przydrożne Lekcje Historii" ("Roadside History Lessons") Foundation, titled Gas Attacks by the Rawka and Bzura in IgIs. The historical path was planned and implemented via related activities such as: in situ workshops using active learning methods; placing information boards located (with active participation of landlords and/or site managers) at the sites of events, with minimal interference in them; publishing the popular science book on traces and testimonies of the Great War on Rawka and Bzura (see: Zalewska, Czarnecki 2016), and production and printing a tourist map issued in a significant amount. All those activities, which can be treated as manifestations of engaged archaeology, 

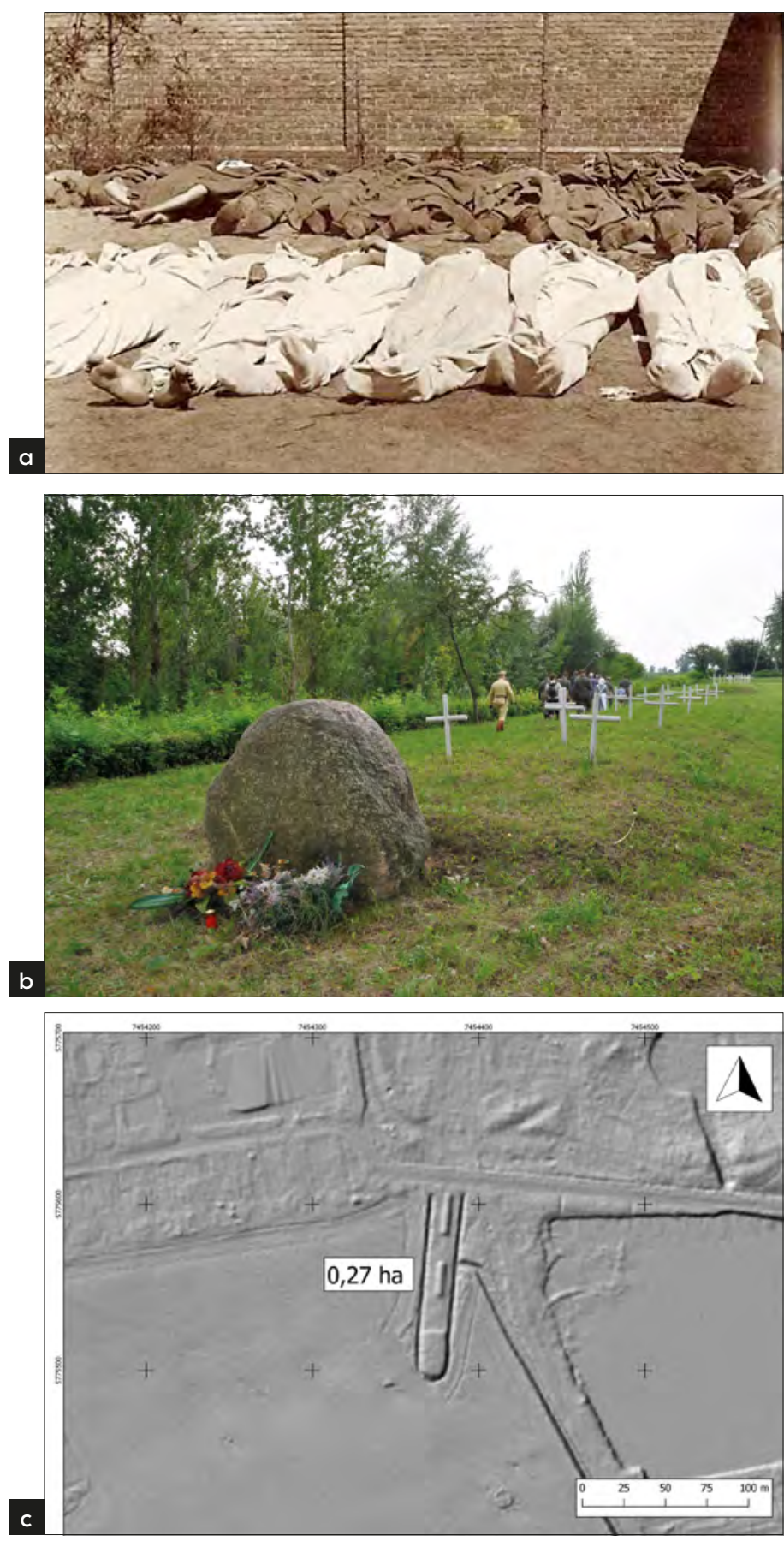

Fig. 5. War cemetery in Guzów in the area of Wiskitki Commune: a. Archive photograph of victims of gas weapons before their burial (1915), courtesy of B. Jagiełło; b. Present-day view of a well-kept war cemetery with crosses restored as a result of grassroots activities with the support of entities responsible for caring for war cemeteries in Poland. The frame from the film "Buried Memories" directed by Eric Vander Borght for opCw; c. Digital Terrain Model (DTM by Grzegorz Kiarszys). Developed by A.I.Zalewska. 


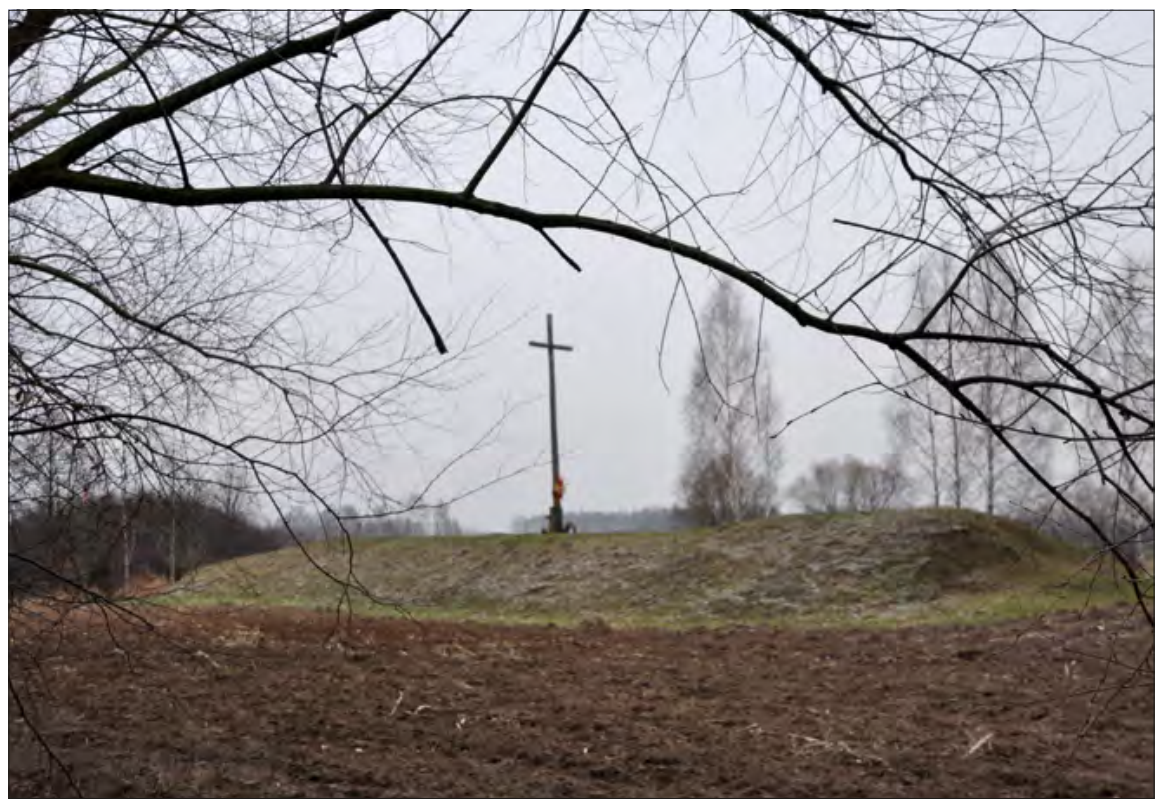

Fig. 6. The mass grave of soldiers of the Russian army in Miedniewice, where rest the victims of use of chemical weapons in the area of Wiskitki Commune. Foto by A.I.Zalewska (2020).

contributed to the pro-social and educational projects, as for example Archaeology of Reconciliation... (see: Zalewska 2015b: 166 et seq.). Also some remains were presented at exhibitions in local memorial halls in Bolimów and Nowa Sucha as well as in Polish Army Museum in Warsaw.

The current length of the path is around $25 \mathrm{~km}$. It runs across the area of the communes of Bolimów (in Łódź Province) and Nowa Sucha (in Mazovian Province). There is also a longer variant, around $36 \mathrm{~km}$ long, with additional section running through Sochaczew commune (in Mazovian Province).

Virtually, the repository could be composed of geospatial data, allowing to precisely locate a particular place in the field, and factual data, including iconographic, text and audio content, etc. Such data could be activated/called-up by potential users e.g. via virtual geolocations of individual points of interest or, in case of direct in situ contact, via QR or similar codes. There is still much to be done in this regard.

In reality, on the material level, the January gas shells attacks as well as three wave attacks carried out by the army of the German Empire with the use of chlorine (and possibly phosgene) left in situ (i.e. at the place of their implementation) only indirect traces. These include, first of all, the very location of those events, (i.e. the landscape that, especially in the northern part of the area discussed herein, 
underwent a radical transformation), as well as graves of fallen soldiers, including victims of gas attacks. They still serve as a powerful reminder of the past. Thus, it would be a good idea to ensure that information on those material remains are documented, collected and systematized in the form of a digital repository of knowledge (here on gas attacks on the Eastern Front) before they disappear completely by natural decay. Such a repository could be composed of geospatial data, allowing to precisely locate a particular place in the field, and factual data, including iconographic, text and audio content, etc.

Data related to the $\mathrm{CW}$ could be also activated/called-up by potential users e.g. via virtual geolocations of individual points of interest or, in case of direct in situ contact, via $Q R$ or similar codes. A good example of the complexity of (dis)appearance of one of the last 'substitute witnesses' to the event from igis could be the area within the present-day administrative boundaries of Wiskitki Commune, where many cemeteries with graves of victims are located (for details concerning war cemeteries in the area of Wiskitki Commune see: Zalewska et al. 2018). These are at a relatively short distance from each other where simultaneously last the war cemetery in the village of Guzów (Fig. 5) and the mass graves in Miedniewice (Fig. 6). The first one is the most well-kept and visible on the surface from among all burial sites of the fallen victims of the $\mathrm{Cw}$ located within that commune), while the second one - the largest in the area remain very problematic, both due to their defective official status (they are currently parts of private recreational plots of land) and gradual (not only natural) decay (material traces of lack of care and respect are clearly observable in their state of preservation). Relating to that observation, it is necessary to emphasize here, that certain activities aimed at documenting, consolidating, systematizing and disseminating knowledge about the experiences related to CW in Central Poland should be undertaken immediately. Some disappearing material remains including war cemeteries - resting places of the victims of chemical weapons - prove it.

Summing up, at present, the area (in present days Poland) of a former battlefield, where the army of the German Empire repeatedly used chemical weapons in I915, still conceals the bodies of - until recently - almost completely forgotten victims of $\mathrm{Cw}$. Attentive travellers can choose - depending on their preferences and possibilities - 4 stops/lessons (basic route) or I2 stops, including the section of Path No. I titled "Life and Death in the Trenches of the World War I by the River Rawka", as well as the Stop of Memory of the Great War on the Way to Independence (I9I8-2018), created in 20I8. That stop was established on the initiative of the Commune Cultural Centre and the authorities of Nowa Sucha, in cooperation with an archaeologist and polemologist. It presents educational content concerning gas attacks in the form a board exhibition.

In addition, it should be emphasized that the state of preservation of those in situ material remains is in many cases very poor (due to agricultural and forest 
land management, as well as very intense treasure hunting with metal detectors in the area, including war cemeteries). They need support, prostheses of memory, prior preparation to make them more evocative. However, even they are still able to support actions aimed at presentification of the reminders of using chemical weapon of mass destruction over century ago. Thanks to the analysis of remote sensing data, including the Digital Terrain Model, created as a derivative of LiDAR scanning and surface examination, the exact locations of some resting places of $\mathrm{CW}$ victims was possible to be determined (Zalewska, Kiarszys 2015; 2017).

Considering the difficult subject matter and sensitive character of material signs encountered by anyone potentially interested in contact with in situ traces of gas attacks, it seems that considerable efforts should be invested in making the message of places, objects and collected data concerning the use of weapons of mass destruction in the territory of present-day Poland fully understandable for contemporary people, especially the youth (i.e. with the use of modern, digital technologies, but also with showing an appropriate respect for those places-witnesses and gasscape as such).

\section{Conclusion}

The use of chemical weapon on the Eastern Front in igis in the region of the rivers Bzura and Rawka confirmed how cruel, and at the same time unpredictable, that weapon was and can be. The passing of time has shown in turn how fleeting the contemporary desire to remember about some episodes of dreadful history can be, and how and how it affects the condition of its last witnesses - the material remains. Conclusions arising from the analysis of both the depositional context and post-depositional processes can provide a stimulus for reflection on the volatility (in both metaphorical and literal sense) of even one of the most extreme and abnormative events form cultural and material memories. Direct contact with the real and mental gasscape experienced by multiple rounds of gas shells fired in January and February 1915, or wave attacks with poisonous chlorine in May, June and July of the same year is a good motivation, or starting point to trigger the desire to know more, to reflect on the escalation in WMD use and war in general. It should be also emphasized that experiments with and combat use of various active chemical agents in the Eastern Front in 1915 contributed, either directly (in the first stage of war) or indirectly, to escalation in the global use of dirty weapons.

Material remains of history of weapons of mass destruction (here chemical weapon on the Eastern Front of the Great War that deserve particular attention due to their specific, volatile nature as well as moral and formal conditions at the stage of the primary process i.e. in 1915 and immediately after the war) - are not easy to comprehend. They cannot be treated as ready-to-use history and/or 
peace education material or proposal for cultural tourism - even reflexive cultural tourism (promoted here as an optimal form of interaction with a difficult heritage such as gasscapes and understood here as demanding significant prior knowledge, above-average commitment incl. engaged preparation covering both the process preceding the contact experience with peculiar witnesses of history and during this type of meeting). On the contrary, they require (cognitive) effort and care (attention and protection). They also constantly need support, 'memory surrogates', to make the message slightly more clear, as some meanings cannot be conveyed through words and, in order to understand them, one must get involved in the material, sensual, corporeal dimension of the world, its very 'presence' or 'substance'.

In this article, I have tried to promote the legitimacy of the pursuit of greater presentification of traces of using chemical weapons from the past - wherever they still exist. This harmonizes with the inalienable necessity of relentless pursuit towards permanent and verifiable elimination of chemical weapons.

I assume that such presentification can be constructively achieved by means of:

- searching for, systematizing and digitalizing source data, e.g. in the form of a digital repository of knowledge on using chemical weapons in the past;

- taking into account and documenting all accessible - as well discursive as material data (including spatial one such as gasscapes), that still bear testimony to the events that took place within at least last century;

- making the areas recognized as testimonies of Cw' uses in the past - the protected zones (e.g. registered historic sites) in order to put them under actual protection and conservator's care to make sure they will be preserved for future generations ${ }^{14}$ andmaking gasscapes and information about them more noticeable, readable and available, according to the cultural context of potentially interested parties, using both direct and indirect information channels at local and global levels, as appropriate;

- interpretating and representating (as much as possible) textual, visual, audial, and material (incl. spatial) carriers of memories and post-memories entangled with the aspects of still partially noticeable traces of using chemical weapons through application of historic, archaeological and scientific research methods;

- taking pro-social actions aimed at treating material signs of using $\mathrm{CW}$ in the past as triggers for reflection, deepening historical sensitivity and awareness and as potential reflective cultural tourism destinations.

Such activities are here perceived as the valuable element of working together for a world free of chemical weapons. Such goal is promoted mainly by the OPCW - the

I4 In Poland, preservation of locations in the Eastern Front of the Great War that are marked with WMD, listed further in this article, could take place in accordance with the provisions of Art. 3, section I, and Art. 3, section 4 of the Act of July 23, 2003 on protection and care of historic monuments (Journal of Laws of 2003, No. 162, item I568, as later amended). 
implementing body for the Convention on the Prohibition of the Development, Production, Stockpiling and Use of Chemical Weapons and on Their Destruction ${ }^{15}$.

The set of places and contents providing a stimulus for reflection on the history of weapons of mass destruction can and should be open, constantly broadened and supplemented, as well as generally accessible. Presentification should possibly be accompanied with a set of generally accessible information (e.g. via the Internet), helpful in reaching the goals of people interested in history of $\mathrm{CW}$ and actions taken in order to stop the still the ongoing process of proliferation of chemical weapons, as well as difficult heritage and attentive travel or reflective cultural tourism. This could be supported by way of making the data available on the Open Access principles, but with consideration for intellectual property of individuals previously engaged in collecting and interpreting that data.

Establishment of a repository of $\mathrm{cw}$ heritage could take place in both virtual and physical space (depending on the needs and skills). It could be either selective, i.e. providing reference at the local level (e.g. to gas attacks in Poland in 1915), or inclusive, i.e. taking into account all recognized places that are important for transnational memory and history of the use of chemical weapons.

While systematizing, storage, connecting, preservation and making public real virtual and digital heritage of chemical weapon we should keep looking for new channels of knowledge transfer (such as audio, visual ${ }^{16}$, etc.), targeted at widening the audience and proving how useful in learning, interpreting, experiencing and gaining awareness can be as well discursive as material remains. These unique warnings, including carriers of memory and knowledge on local history of global significance have the power (potential) for stimulating and encouraging us to think, to actively show empathy and finally to be more attentive to the events of the $20^{\text {th }}$ century that have strongly marked our world, and which still threaten the world today.

\section{Acknowledgements}

I thank Dr Craig Cormick for valuable comments on this text and for the linguistic proofreading as well as for the long-term commitment and constructive cooperation in the field of outreach and education activities related to disarmament and non-proliferation of chemical weapon. The research 'Archaeology of the Eastern

I5 See details on the Chemical Weapons Convention and opCw mission on https://www.opcw.org/.

I6 See for example results of very interesting and stimulating initiative for outreach and education by OPCW - a series of short documentary videos depicting the intersection of people and chemical weapons - The Fires (https://www.opcw.org/fires). There, among other things, an insight into the issues discussed in this article Buried Memories at the https://www.opcw.org/fires, https://youtu.be/U7b5fmoesQI. 
Front of the Great War and the legacy of armed conflicts as a cognitive, social and curatorial challenge' (No. 4445/20/FPK/NID) is co-financed by the Minister of Culture and National Heritage from the Culture Promotion Fund, obtained from subsidies established in games subject to state monopoly, in accordance with Art.80 sec.I of the Act of November 19, 2009 on gambling.

\section{Bibliography}

Archeologiczne przywracanie pamięci o Wielkiej Wojnie w rejonie Rawki i Bzury (I9I4-I9IS) I9I9, A.I. Zalewska (ed.), Wydawnictwo IAE PAN, Warszawa.

Bartel Z. (1928), Broń gazowa, Warszawa.

von Bayern Prinz Leopold (1915), Das personliche Tagebuch, Nachlass Prinz Leopold 239, Bayerisches Hauptstaatsarchiv, Geheime Archiv (typescript).

Friedrich B., James J. (2017), From Berlin-Dablem to the Fronts of World War I: The Role of Fritz Haber and his Kaiser Wilhelm Institute in German Chemical Warfare, [in:] F. Bretislav, H. Dieter, R. Jürgen, S. Florian, W. Martin (ed.), One Hundred Years of Chemical Warfare. Research, Deployment, Consequences, Springer, Cham, p. 25-44, https://doi.org/IO.I007/978-3-319-51664-6_3

Gebhardt O. (1933), Geschichte des Res.-Inf.-Regts. Nr. 228, Dritter Teil, Von Brzeziny bis Bolimow (n.p.).

Haber L.F. (2002), The Poisonous Cloud, Clarendon, Oxford.

Hulka-Laskowski P. (1934), Mój Żyrardów. Z dziejów polskiego miasta i z życia pisarza, Wydawnictwo J. Przeworskiego, Warszawa.

Innocence Slaughtered. Gas and the Transformation of Warfare and Society (20I5), J.P. Zanders (ed.), London.

Kaliński S. (2015), Bolimów I9I5, Wydawnictwo Bellona, Warszawa.

Kowalczyk A. (2008), Turystyka Kulturowa. Spojrzenie geograficzne, Uniwersytet Warszawski, Warszawa.

Lepick O. (I998), La Grande Guerrechimique I9I4-I9I8, Presses Universitaires de France, Paris.

Liddell R.S. (1916), On the Russian Front, Simpkin, Marshall \& Co, London.

Martinetz D. (1996), Der Gaskrieg 19I4/I8. Entwicklung, Herstellung und Einsatz chemischer Kampfstoffe. Das Zusammenwirken von militärischer Führung. Wissenschaft und Industrie, Bernard und Graefe, Bonn.

McKercher B., DuCros H. (2003), Testing a Cultural Tourism Typology, "International Journal of Tourism Research", 5 (I), p. 45-58, https://doi.org/IO.IOO2/jtr.4I7

Przecławski K. (1979), Socjologiczneproblemy turystyki, Instytut Wydawniczy crzz, Warszawa. RGVIA (Rossijskij Gosudarstvennyj Voenno-Istoričeskij Arhiv.) f. (nn), o. I, d. 84. Richter W. (193I), Das Danziger Infanterie Regiment Nr. I28, Sporn, Zeulenroda.

Rozdżestwieński P. (20II), Żyrardów - zniszczony cmentarz z I Wojny Światowej, https://dobroni.pl/artykul/zyrardow--zniszczony/569253 (access 5 V 2020).

Spiers E. (2016), The Gas War, I9I5-I9I8: If not a War Winner, Hardly a Failure, [in:] B. Friedrich, D. Hoffmann, F. Schmaltz, J. Renn, M. Wolf (ed.), One Hundred 
Years of Chemical Warfare. Research, Deployment, Consequences, Springer, Heidelberg, p. I53-168, https://doi.org/I0.1007/978-3-319-51664-6_9

Stoltzenberg D. (1994), Fritz Haber. Chemiker, Nobelpreisträger, Deutscher, Jude, vcH, New York-Cambridge-Tokyo.

Śliwakowski M., Chałas A. (2019), Poszukiwanie śladów użycia substancji drażniących. Analiza próbek z rejonu walk prowadzonych w czasie I wojny światowej w okolicach Bolimowa, [in:] A.I. Zalewska (ed.), Archeologiczne Przywracanie pamięci o Wielkiej Wojnie $w$ rejonie Rawki i Bzury (I9I4-I9I5), Wydawnictwo IAE PAN, Warszawa, p. II3-II7.

Zalewska A.I. (2013), Roadside Lessons of Historicity. The Roles and the Meanings of the Material Points of References to The Great War and in Shaping Historical Sensitivity and Awareness, "Sensus Historiae", I3 (2013/4), p. 69-85.

Zalewska A.I. (2015a), Miejsca w pamięci. Stanowiska archeologicznej jako pola artykulacji pamięci w kontekście studiów i kategorii pamięcioznawczych, [in:] B. Gediga, A. Grossman, W. Piotrowski (ed.) Miejsca pamięci-pradzieje, średniowiecze i wspótczesność, Biskupin-Wrocław, p. 6I-78.

Zalewska A.I. (2015b), Między ztem a dobrem kultury. Niematerialne wartości materialnych pozostatości po XX-wiecznych konfliktach, [in:] Z. Kobyliński, J. Wysocki (ed.) Konserwacja Zapobiegawcza. Dziedzictwo niematerialne i pamięć, uksw, Warszawa, p. I6I-I68.

Zalewska A.I. (2016), The 'Gas-scape' on the Eastern Front, Poland (I9I4-20I4): Exploring the Material and Digital Landscapes and Remembering Those 'Twice-Killed', [in:] B. Stichelbaut, D. Cowley (ed.), Conflict Landscapes and Archaeology from Above, Routledge, London, p. I47-165.

Zalewska A.I. (2019), Historia użycia przez armię niemiecką broni masowego rażenia (Massenwirkung) w rejonie Rawki i Bzury w styczniu I9Is roku, [in:] A.I. Zalewska (ed.), Archeologiczne przywracanie pamięci o Wielkiej Wojnie w rejonie Rawki i Bzury (I9I4-I9I5), Wydawnictwo IAE PAN, Warszawa, p. 99-II2.

Zalewska A.I., Cyngot D. (20I7), Problem zanikania pamięci o miejscach spoczynku żotnierzy polegtych $w$ walkach nad Rawka i Bzura w latach I9I4-I9I5, "Acta Universitatis Lodziensis. Folia Archaeologica", 32, p. II9-I56, https://doi.org/IO.I8778/0208-6034.32.06

Zalewska A.I., Cyngot D. (2020), Wptyw wojennych wydarzeń dziejowych (res gestae) i relacji o nich (historia rerum gestarum) na kondycje materialnych pozostatości po tych wydarzeniach. Studium przypadku na temat dziedzictwa konfliktów zbrojnych jako wyzwania poznawczego i spotecznego, "Folia Praehistorica Posnaniensia", 25 (in print).

Zalewska A.I., Cyngot D., Czarnecki J., Kiarszys G. (2018), Miejsca spoczynku polegtych $w$ toku Wielkiej Wojny nad Rawka i Bzura - ich zaistnienie, trwanie i zanik... oraz poznanie i ochrona, [in:] M. Karczewska (ed.), Cmentarze wojenne I wojny światowej po stuleciu. Stan badań i ochrony, Ośrodek Badań Europy Środkowo-Wschodniej, Białystok, p. 7I-IO2.

Zalewska A.I., Czarnecki J. (20I6), Ślady i świadectwa Wielkiej Wojny nad Rawkq i Bzura, Fundacja Przydrożne Lekcje Historii, Warszawa.

Zalewska A.I., Czarnecki J. (2019), ... Zastój na catej linii. Historia przejścia od wojny manewrowej do pozycyjnej na przyczótku bolimowskim (I9I4/I9IS), [in:] A.I. Zalewska (ed.), Archeologiczne przywracanie pamięci o Wielkiej Wojnie w Rejonie Rawki i Bzury (I9I4-I9I5), Wydawnictwo IAE PAN, Warszawa, p. 27-4I. 
Zalewska A.I., Czarnecki J. (in print), Conflict Gas-scape. Chemical Weapons on the Eastern Front in January I9I5, [in:] N.J. Saunders, P. Cornish (ed.), Conflict Landscapes Materiality and Meaning in Contested Places.

Zalewska A.I., Kiarszys G. (2015), Sensing the Material Remains of the Forgotten Great War in Poland. Sensibly or Sensationally - The Dilemma in Front of Presenting Results of the Airborne Laser Scanning Visualizations, [in:] A.G. Posluschny (ed.), Sensing the Past. Contributions from the ArcLand Conference on Remote Sensing for Archaeology, Arcland, Bonn, p. 72-73.

Zalewska A.I., Kiarszys G. (2017), Absent Presence of Great War Cemeteries in the Municipality of Bolimow, Central Poland, [in:] A.I. Zalewska, J.M. Scott, G. Kiarszys (ed.), The Materiality of Troubled Pasts. Archaeologies of Conflicts and Wars, Fundacja Przydrożne Lekcje Historii, usz, Warszawa-Szczecin 2017, p. 55-82.

Zalewska A.I., Czarnecki J., Kiarszys G. (2019), Krajobraz Wielkiej Wojny. Front nad Rawką i Bzura (I9I4-I9IS) w świetle teledetekcji archeologicznej i źródet historycznych, Wydawnictwo iae pan. Fundacja Przydrożne Lekcje Historii, Warszawa.

Zalewska A.I., Cyngot D., Czarnecki J., Kiarszys G. (2018), Miejsca spoczynku polegtych w toku Wielkiej Wojny nad Rawka i Bzurq - ich zaistnienie, trwanie i zanik ... oraz poznanie i ochrona, [in:] M. Karczewska (ed.), Cmentarze wojenne I wojny światowej po stuleciu. Stan badań i ochrony, OBEśw, Białystok, p. 7I-IO2.

\section{Summary}

The Use of Chemical Weapons on the Eastern Front of World War One (1915) and its Material and Discursive Remains - the Challenge and Stimuli for Attentive Travel, Systematizing, Storage, Connecting, in situ Preservation and Making Public Real Virtual and Digital Heritage of Weapons of Mass Destruction

The article includes a theoretical and practical proposal for perceiving and treating material and discursive remains of using chemical weapons - wherever they still exist - as stimuli for reflection on weapons of mass destruction and as warnings. Based on the specific example of the outcomes of the archaeological and historical research conducted in the historic battlefield - the section of the Eastern Front between Sochaczew in the north and Skierniewice in the south, the following more general appeals have been formulated: - for inalienability of collecting, systematizing and interpreting source information and studies that could together make up a real and digital repository of knowledge on material and discursive remains of historical uses of chemical weapons (Cw) and potentially further on of weapons of mass destruction (WMD); - for documenting, digitalising and protecting in situ remains of the past that, despite representing a challenge for contemporary people, constitute a part of important, however difficult, transnational painful heritage; - for undertaking more intense, systematic and coordinated activities to disseminate knowledge about past use of $\mathrm{CW}$ and about the mission and activities of individuals and organisations involved in the process of minimizing the threats of weapons of mass destruction in the modern world (such as the Organisation for the Prohibition of Chemical Weapons - OpCW).

It is worth exploration, as well as documentation and protection (with the aid of archaeology, history, memory studies, ethnology, landscape studies, educational studies - especially on 
Peace Education, tourism studies etc.) e.g. by means of transdyscyplinary research and working on establishing real and virtual repositories of knowledge on CW, OPCW, outreach, education on transnational painful heritage, reflective cultural tourism, attentive travel etc.

The historical gasscapes (landscape marked with gas attacks) - such as an element of the landscape of today's central Poland, sketched in this article, that bore witness to the very first mass use of gas shells in January 1915, as well as wave attacks with poisonous chlorine (possibly combined with phosgene) in the battlefield, has been presented as particularly predestined to serve as a symbols of $\mathrm{CW}$ painful heritage, triggers for reflection on BMR and carriers of even though weaker and disappearing living memories. Additionally, the attention was drawn to the fact that certain activities aimed at documenting, consolidating, systematizing and disseminating knowledge about the experiences related to $\mathrm{CW}$ (or more broadly, WMD) should be undertaken immediately. Some disappearing material remains prove it. The area (in present days Poland) of a former battlefield, where the army of the German Empire repeatedly used chemical weapons in 1915, still conceals the bodies of - until recently - almost completely forgotten victims of $\mathrm{Cw}$. Hence the emphasis put on the significance of that area and other similar places as destinations for attentive travel (real and virtual) following evocative remains will not leave us indifferent and uninterested.

Keywords: weapons of mass destruction (WMD), chemical weapon (CW), material and discursive remains of cw, World War I, Eastern Front, I9I5, central Poland, gasscape, war cemeteries, archaeology, memory, transnational painful heritage, real and virtual repositories of knowledge on CW, OPCW, outreach, education, reflective cultural tourism, attentive travel

\title{
Streszczenie
}

\begin{abstract}
Użycie broni chemicznych na Froncie Wschodnim I wojny światowej (1915) oraz materialne i dyskursywne pozostałości jako wyzwanie i stymulator dla uważnego podróżowania, ochrony in situ oraz systematyzacji, przechowywania i upubliczniania realnego, wirtualnego i cyfrowego dziedzictwa broni masowego rażenia
\end{abstract}

Artykuł zawiera teoretyczną i praktyczną propozycję postrzegania i traktowania materialnych i dyskursywnych pozostałości po użyciu broni chemicznej - wszędzie tam, gdzie jeszcze istnieją - jako bodźców do refleksji nad bronią masowego rażenia i jako ostrzeżeń przed jej stosowaniem. Na konkretnym przykładzie wyników badań archeologiczno-historycznych prowadzonych na historycznym polu bitwy - stanowiącym pozostałość po odcinku Frontu Wschodniego między Sochaczewem na północy a Skierniewicami na południu - sformułowano następujące argumenty (wykraczające poza omawiane tu studium przypadku) i przemawiające za:

- zasadnością i niezbywalnością gromadzenia, systematyzowania i interpretowania informacji źródłowych i badań, które mogłyby przyczynić się do zaistnienia repozytorium wiedzy o materialnych i dyskursywnych pozostałościach historycznych zastosowań broni chemicznej (CW) i broni masowego rażenia (BMR);

- potrzebą dokumentowania, digitalizacji i ochrony in situ pozostałości przeszłości, które są częścią ważnego, choć trudnego, transnarodowego bolesnego dziedzictwa;

- koniecznością podjęcia bardziej intensywnych, systematycznych i skoordynowanych działań upowszechniających wiedzę o stosowaniu broni chemicznej w przeszłości oraz 
- celowością upowszechniania wiedzy o misji i działalności osób i organizacji zaangażowanych w proces minimalizowania zagrożeń wynikających ze stosowania broni masowego rażenia we współczesnym świecie, jak np. Organizacja ds. Zakazu Broni Chemicznej (OPCW - skrót od ang. Organisation for the Prohibition of Chemical Weapons).

W artykule zaprezentowane zostały argumenty przemawiające za tym, że warto badać, dokumentować, zabezpieczać, interpretować i uobecniać w przestrzeni publicznej wiedzę o stosowaniu broni chemicznej, np. poprzez tworzenie repozytoriów (z wykorzystaniem przestrzeni realnych i wirtualnych oraz materialnych i cyfrowych danych), refleksyjną turystykę kulturową i uważne podróżowanie. Mogłoby to następować poprzez transdycysplinarne działania np. z udziałem archeologii, historii, studiów nad pamięcią, etnologii, krajobrazoznawstwa, pedagogiki (zwłaszcza edukacji dla pokoju), studiów nad turystyką itp.

Historyczne krajobrazy gazowe (krajobrazy naznaczone atakami gazowymi określane tu jako gasscapes) - jak m.in. naszkicowany w tym artykule element krajobrazu dzisiejszej centralnej Polski, który był świadkiem pierwszego masowego użycia przez armię niemiecką pocisków gazowych w styczniu I9I5 r., a także ataków falowych z wykorzystaniem trującego chloru (prawdopodobnie $\mathrm{z}$ fosgenem), zostały w artykule przedstawione jako predestynowane do tego, by służyć nam i przyszłym pokoleniom jako symbole bolesnego dziedzictwa broni chemicznej.

Dodatkowo zwrócono uwagę, że pewne działania mające na celu poznawanie, dokumentowanie, utrwalanie, obejmowanie formalną ochroną i opieką śladów i świadectw, systematyzowanie i upowszechnienie wiedzy o doświadczeniach związanych z bronią chemiczną (czy szerzej bronią masowego rażenia), powinny zostać podjęte niezwłocznie. Przemawiają za tym m.in. bezpowrotnie znikające pozostałości materialne (jak np. cmentarze wojenne, na których spoczywają ofiary zastosowania broni chemicznej), będące ostatnimi świadkami. Teren dawnego pola bitwy (na Równinie Łowicko-Błonskiej), na którym armia Cesarstwa Niemieckiego wielokrotnie użyła broni chemicznej w roku I915, nadal kryje szczątki do niedawna prawie całkowicie zapomnianych ofiar broni masowego rażenia. Stąd nacisk kładziony na znaczenie tego obszaru i innych podobnych miejsc jako destynacji uważnych podróży (realnych i wirtualnych), które nie powinny nas pozostawiać obojętnymi i niezainteresowanymi.

Słowa kluczowe: broń masowego rażenia (BMR), broń chemiczna (CW), materialne i dyskursywne pozostałości broni chemicznej, I wojna światowa, Front Wschodni, I915, Polska Centralna, krajobraz (po)gazowy, cmentarze wojenne, archeologia, pamięć, bolesne dziedzictwo transnarodowe, rzeczywiste i wirtualne repozytoria wiedzy o cw, OPCW, upowszechnianie wiedzy, edukacja dla pokoju, refleksyjna turystyka kulturowa, uważne podróżowanie

\section{Anna Izabella Zalewska}

Maria Curie-Skłodowska University in Lublin Institute of Archaeology; Institute of History

Poland

e-mail: azalew@op.pl 